\title{
EKSISTENSI DAN DETERMINAN MIDDLE INCOME TRAP DI INDONESIA
}

\author{
(Existence and Determinants of Middle Income Trap in Indonesia) \\ Hotmaria Elecktawati Lumbangaol* dan Ernawati Pasaribu** \\ Statistika Ekonomi Sekolah Tinggi Ilmu Statistik \\ Jalan Otto Iskandardinata No. 64C Jakarta \\ e-mail: *13.7651@stis.ac.id, **ernapasaribu@stis.ac.id \\ Naskah diterima: 30 April 2018 \\ Naskah direvisi: 02 Oktober 2018 \\ Naskah diterbitkan: 31 Desember 2018
}

\begin{abstract}
World Bank has classified that Indonesia has been included in lower-middle income countries in the last 13 years. This shows that Indonesia's economic growth is quite stagnant for a long time and made Indonesia very potential to enter MIT. This study applies to identify whether Indonesia is already included in MIT. The time series analysis of ECM is also used to determine actions that can be taken in the long term to get out or avoid MIT. GNP per capita as the basis classification of income groups of countries in the world used as a variable to see MIT. The results show that both in the short and long term, service sector and high-educated labour have a positive effect to GNP per capita. The agricultural sector has a positive effect only in the short term, while the manufacturing sector is negatively affected in the long term. Economic structure condition that not supported together by these economic sectors show that economic structural transformation did not go well and indicates that Indonesia has fallen into MIT. The government is expected to improve the services sector, PMTB, and high-educated labour and improve the agricultural and manufacturing sectors in Indonesia as a way to get out from MIT and transition to developed countries.
\end{abstract}

Keywords: MIT, GNP per capita, ECM

\begin{abstract}
Abstrak
Bank Dunia mengklasifikasikan negara Indonesia ke dalam kelompok negara dengan pendapatan menengah ke bawah (lower-middle income country) selama 13 tahun terakhir. Hal ini, menunjukkan bahwa pertumbuhan ekonomi Indonesia cukup stagnan dalam waktu yang lama dan membuat potensi Indonesia masuk jebakan pendapatan menengah (Middle Income Trap) sangat besar. Penelitian ini, diantaranya bertujuan untuk mengidentifikasi apakah Indonesia telah masuk dalam MIT. Analisis time series ECM digunakan sekaligus untuk mengetahui tindakan apa yang perlu dilakukan dalam jangka panjang untuk keluar atau terhindar dari jebakan pendapatan menengah. PNB per kapita sebagai dasar pengklasifikasian kelompok pendapatan negara-negara di dunia digunakan sebagai variabel untuk melihat MIT. Didapatkan hasil bahwa baik dalam jangka pendek maupun jangka panjang sektor jasa dan jumlah tenaga kerja berpendidikan tinggi akan berpengaruh positif terhadap PNB per kapita. Sektor pertanian berpengaruh positif hanya dalam jangka pendek, sedangkan sektor manufaktur berpengaruh negatif dalam jangka panjang. Struktur perekonomian yang tidak didukung bersama-sama oleh sektor-sektor ekonomi ini menunjukkan bahwa transformasi struktur ekonomi tidak berjalan dengan baik dan mengindikasikan Indonesia telah masuk dalam jebakan pendapatan menengah. Pemerintah diharapkan dapat meningkatkan sektor jasa, PMTB, dan tenaga kerja berpendidikan tinggi (human capital), serta memperbaiki sektor pertanian dan manufaktur di Indonesia sebagai upaya keluar dari jebakan pendapatan menengah dan bertransisi menuju negara maju.
\end{abstract}

Kata kunci: MIT, PNB per kapita, ECM

\section{PENDAHULUAN}

Indonesia merupakan negara dengan pasar ekonomi terbesar di kawasan Association of South East Asia Nations (ASEAN) dan yang terbesar ke-16 di dunia. Sejak tahun 2009 perekonomian Indonesia mampu mengangkat lebih dari tiga juta orang keluar dari kemiskinan (ADB, 2016). Oberman, et al., (2012:7) dalam laporannya memprediksi bahwa pada tahun 2030 Indonesia akan berada di urutan ke-7 perekonomian terbesar di dunia dan mengestimasi penambahan 90 juta masyarakat Indonesia memasuki kelas konsumsi (paritas daya beli tinggi).

Dilihat dari perkembangan pendapatan per kapitanya, Indonesia menunjukkan peningkatan empat kali lipat periode tahun 1976-2015 (World Bank, 2016). Hal ini membuat Indonesia mampu bertransisi dari negara berpendapatan rendah (low- income country) ke negara pendapatan menengah bawah (lower-midle income country). Namun peningkatan Produk Nasional Bruto (PNB) per kapita Indonesia ini masih jauh lebih rendah dibandingkan negara-negara ASEAN lainnya seperti Singapura, Malaysia, Thailand dan Filipina. Bahkan menunjukkan penurunan dalam dua tahun terakhir di USD3.440 tahun 2015.

Peningkatan pendapatan ini juga tidak dirasakan secara merata oleh masyarakat Indonesia. Kemajuan ekonomi ini lebih banyak dinikmati oleh mereka yang berpendapatan tinggi. Terbukti dengan jumlah penduduk miskin Indonesia yang sebesar 28,01 juta orang (BPS, 2015). Bahkan masih terdapat 72,01 juta penduduk Indonesia yang rentan di atas garis kemiskinan. Jika terjadi gejolak ekonomi, maka penduduk yang rentan di atas garis kemiskinan ini 
akan beralih dengan cepat menambah penduduk miskin di Indonesia. Selain itu indeks gini Indonesia menunjukkan ketimpangan yang makin melebar, dimana pada tahun 2015 telah mencapai angka 0,41 (BPS, 2016).

Kemiskinan dan ketimpangan ini pada gilirannya dapat mengakibatkan Indonesia mengalami perlambatan pertumbuhan. Di tengah situasi ekonomi global yang belum sepenuhnya kondusif, perekonomian Indonesia sendiri secara umum masih belum stabil. Hal ini ditunjukkan oleh pertumbuhan PNB per kapita Indonesia dalam lima tahun terakhir cenderung mengalami penurunan. Perlambatan ini dipicu oleh penurunan produksi di beberapa lapangan usaha yang berkontribusi besar dalam perekonomian seperti industri $(-0,53 \%)$, perdagangan $(-0,41 \%)$ dan juga pertanian $(-0,28 \%)$.

Secara keseluruhan output perekonomian Indonesia mengalami perlambatan dari tahun 20102015. Perlambatan perekonomian ini jika dibiarkan terus berlangsung akan memperburuk perekonomian Indonesia. Laju pertumbuhan ekonomi Indonesia yang hanya berkisar 4 sampai 6 persen tidak akan mampu memenuhi permintaan penduduk yang terus bertambah. Bahkan dengan laju pertumbuhan ekonomi sebesar ini, bonus demografi yang seharusnya jadi potensi Indonesia beberapa tahun ke depan akan menjadi masalah seperti pengangguran besar-besaran.

Dalam jangka panjang, kondisi perekonomian yang stagnan bahkan cenderung menurun membuat resiko Indonesia semakin kuat untuk masuk ke dalam jebakan pendapatan menengah (Middle Income Trap/ MIT). Agenor, Canuto, \& Jelenic dalam World Bank Economic Premise (2012) mendefinisikan MIT sebagai keadaan suatu negara yang mengalami stagnasi petumbuhan di tingkat pendapatan menengah dan tidak berkembang ke tingkat pertumbuhan ekonomi selanjutnya ke pendapatan tinggi.

Jika masuk ke dalam MIT, maka Indonesia tidak akan dapat bertransisi menuju negara maju. Selain itu, MIT secara tidak langsung akan menyebabkan konflik sosial. Tidak hanya akan membuat Indonesia sulit bersaing dengan negara maju, namun juga dengan negara berkembang lainnya.

Berdasarkan kondisi tersebut penting untuk mengetahui bagaimana kondisi perekonomian Indonesia saat ini, apakah telah memasuki MIT atau tidak. Untuk menghindari/keluar dari MIT diperlukan strategi pembangunan yang tepat di Indonesia. Dengan demikian, Indonesia diharapkan mampu menjadi negara maju dengan pendapatan tinggi di tahun 2030.

Penelitian terkait sebelumnya telah dilakukan oleh Robertson dan Ye (2013) dengan menguji negara-negara masuk ke dalam MIT secara time series. Aviliani et al. (2014) menguji MIT untuk studi kasus Indonesia dan menyimpulkan bahwa Indonesia belum masuk dalam MIT. Sementara Malale dan Sutikno (2014) menyimpulkan bahwa Indonesia telah masuk MIT. Perbedaan hasil ini bisa jadi karena menggunakan pendekatan dan metode penelitian yang berbeda. Dengan menggunakan pendekatan Error Correction Model (ECM), penelitian ini diharapkan dapat menghasilkan identifikasi yang lebih tepat terkait MIT di Indonesia.

\section{Middle Income Trap (MIT)}

Secara konseptual, MIT merupakan fenomena yang relatif baru dan pertama kali disebutkan pada tahun 2007 dalam laporan Bank Dunia yang berjudul An East Asian Renaissance: Ideas for Economic Growth (Gill dan Kharas, 2007:17-18). Penelitian lain mendefinisikan MIT sebagai kondisi dimana negaranegara berpenghasilan menengah tidak mampu mempertahankan tingkat pertumbuhan ekonomi yang cukup stabil untuk mencapai kelompok income yang baru sebagai negara berpenghasilan tinggi sehingga terjebak dalam kelompok middleincome (Aviliani et al., 2014). Eichengreen et al. (2013) mendefinisikan MIT sebagai perlambatan pertumbuhan di ekonomi pasar pada negara berkembang.

Glawe dan Helmut (2016) membagi MIT ke dalam dua kelompok yaitu definisi teoritis dan definisi empiris. Secara teoritis MIT adalah hasil dari kehilangan reformasi struktural dan institusional (semacam kegagalan politik). Menurut Kharas dan Kohli (2011:282) dalam Glawe dan Helmut (2016), negara terjebak dalam MIT jika tidak dapat bertransisi dalam waktu yang tepat dari pertumbuhan sumber daya dengan tenaga kerja dan modal yang murah. Kelemahannya, definisi teoritis masih ambigu dalam menggolongkan suatu negara memasuki MIT atau tidak.

Secara visual Ohno (2009) mendefinisikan MIT seperti pada gambar 1. Stage zero pada gambar 1 mencirikan negara dengan pendapatan rendah. Pada umumnya perekonomian negara ini masih berorientasi pada pertanian subsisten. Tahapan ini masih jauh menuju industrialisasi. Untuk stage one jika dilihat dari sudut pandang negara Asia Timur, perekonomian telah mulai dengan jumlah manufaktur yang cukup. Elektronik sudah mulai diproduksi pada tahapan ini. Namun, pada stage one ini desain, teknologi, produksi dan pemasaran masih dipimpin oleh negara asing dan masih mengimpor material-material penting dalam proses produksi. Pada tahapan ini suatu negara hanya berkontribusi pada tenaga kerja tidak terlatih dan lahan industri. 


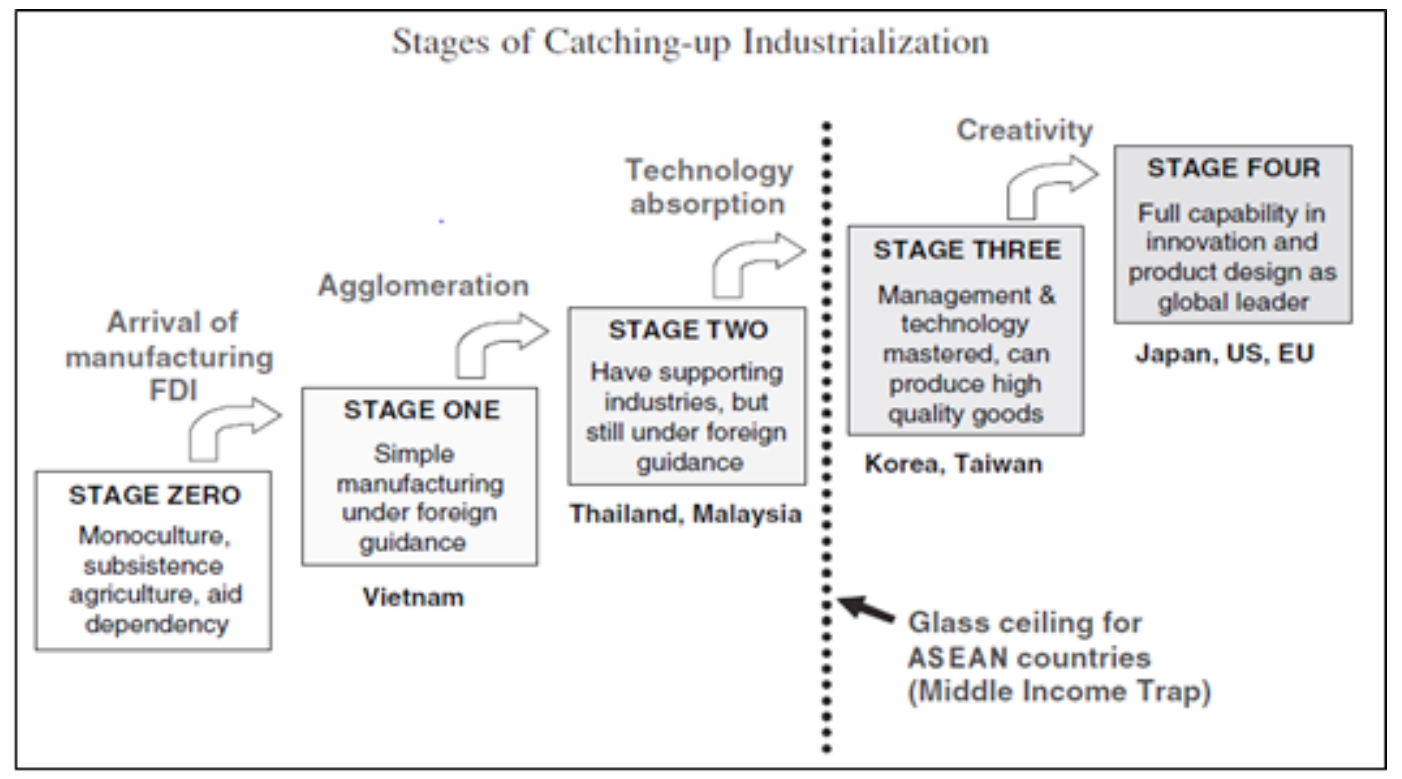

Sumber: Ohno (2009)

Gambar 1. Tahapan Perkembangan Perekonomian Suatu Negara

Pada second stage, akumulasi modal asing dan produksi berkembang, penawaran dalam negeri mulai meningkat. Di tahap ini, modal mulai mengalir sampai kepada produsen lokal. Industri dan kreativitas tumbuh dengan baik, tetapi dasar produksi masih berada dalam manajemen dan arahan negara luar. Jelas, upah lokal dan pendapatan tidak bisa meningkat banyak karena perekonomian sebagian besar masing dikuasai oleh asing.

Tahapan selanjutnya adalah meningkatkan kemampuan dan pengetahuan modal manusia. Suatu negara harus menggantikan peran orang asing di seluruh kegiatan produksi. Saat ketergantungan terhadap negara lain ini berkurang maka kemampuan dalam negeri akan meningkat dan dapat bersaing sendiri dengan industri global. Pada tahap akhir, suatu negara dicirikan dengan kemampuan untuk membuat produk baru dan dapat memimpin pasar global.

Bagaimanapun tahapan ini tidak berjalan dengan mulus bagi semua negara. Sebagian besar negara yang menerima sedikit faktor manufaktur bertahan pada stage zero. Seandainya pun dapat mencapai stage one, masih sangat sulit untuk mencapai tahap berikutnya. Negara lainnya terjebak dalam second stage karena gagal untuk meningkatkan modal manusianya. Dalam penelitiannya Ohno (2009) mengungkapkan tidak satupun negara ASEAN mampu memecahkan "glass ceiling" yang menjadi pembatas antara stage two dan stage three. Dengan kata lain belum dapat berpindah dari tahap dua ke tahap tiga. Bahkan sebagian besar negara Amerika latin masih tetap berada dalam pendapatan menengah meskipun mereka telah berhasil mencapai pendapatan yang relatif tinggi pada awal abad sembilan belas. Seluruh fenomena inilah yang disebut sebagai middle income trap.

\section{Kerangka Pikir}

Menurut klasifikasi Bank Dunia, Indonesia telah masuk dalam kelompok negara pendapatan menengah ke bawah (lower-middle income country) dalam 13 tahun terakhir. Hal ini menunjukkan bahwa pertumbuhan ekonomi Indonesia tidak menunjukkan pertumbuhan yang berarti dalam waktu yang lama dan membuat potensi Indonesia masuk ke MIT sangat besar. Penelitian ini diantaranya bertujuan untuk menunjukkan faktor-faktor yang menyebabkan mengapa MIT terjadi. Analisis ECM digunakan untuk mengetahui faktor penyebab MIT dan tindakan yang dapat diambil dalam jangka panjang.

Dalam penelitian ini untuk mengetahui apakah Indonesia telah memasuki MIT atau tidak, dapat dilihat melalui pendapatan nasional penduduk yang dinyatakan dalam PNB per kapita. Faktor-faktor yang memengaruhi PNB per kapita agar Indonesia terhindar dari MIT dijelaskan secara teoritis melalui kerangka pikir.

Berdasarkan teori transfomasi struktural dijelaskan bahwa fenomena terjadinya perubahan struktur ekonomi suatu negara menuju negara maju pada umumnya bergerak bertahap dari sektor primer (pertanian), ke sektor sekunder (industri) dan tersier (jasa) (Todaro, 2003) dan merujuk pada penelitian sebelumnya, maka ditarik hipotesis bahwa variabel independen yang dinyatakan memengaruhi pertumbuhan ekonomi adalah Pembentukan Modal Tetap Bruto (PMTB), nilai tambah sektor pertanian, nilai tambah sektor manufaktur, nilai tambah sektor jasa, dan human capital yang dilihat melalui tenaga kerja berpendidikan tinggi. Kerangka pikir pada penelitian ini dapat dilihat pada Gambar 2 berikut: 


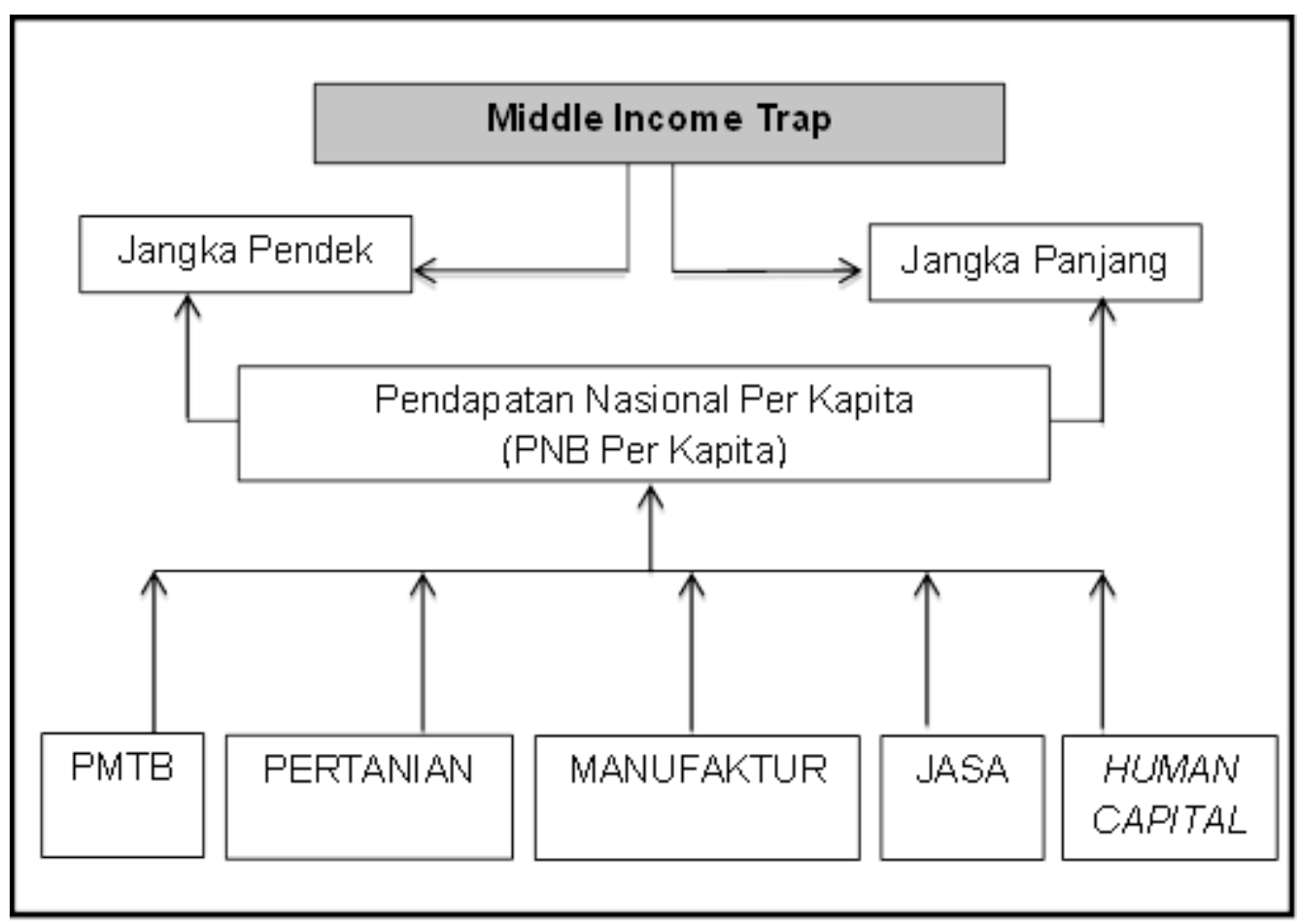

Gambar 2. Kerangka Pikir

\section{METODOLOG}

Data yang digunakan dalam penelitian ini adalah data time series dengan periode waktu mulai tahun 1976 sampai dengan 2015 yang terdiri dari 40 unit observasi. Variabel yang digunakan dalam penelitian ini adalah PMTB, nilai tambah pertanian, nilai tambah manufaktur, nilai tambah jasa dan tenaga kerja dengan pendidikan tinggi sebagai variabel independen. Middle income trap di Indonesia sebagai variabel dependen dilihat berdasarkan PNB per kapita.

\section{Metode Pengumpulan Data}

Berdasarkan sumbernya, data yang digunakan dalam penelitian ini adalah data sekunder. Data sekunder merupakan data yang diterbitkan oleh organisasi lain yang bukan merupakan pengolahnya (Dajan, 1986:19). Data dalam penelitian ini berasal dari Badan Pusat Statistik (BPS) dan World Development Index (WDI) Bank Dunia. Data PMTB, nilai tambah pertanian, manufaktur, jasa dan tenaga kerja berpendidikan tinggi bersumber dari BPS yang dikumpulkan dari data Sub Direktorat Neraca dan Modal Luar Negeri dan Survei Angkatan Kerja Nasional (Sakernas). Sedangkan data PNB per kapita dikumpulkan melalui akun data bank dunia nasional dan akun data The Organisation for Economic CoOperation and Development (OECD) nasional.

\section{Metode Analisis}

Dalam penelitian ini metode analisis yang digunakan ada dua jenis yaitu analisis deskriptif dan analisis inferensia. Analisis deskriptif digunakan untuk mengetahui posisi dan perkembangan pendapatan Indonesia beserta faktor yang memengaruhinya. Analisis inferensia digunakan untuk menganalisis pengaruh faktor-faktor terhadap PNB per kapita Indonesia.

Analisis inferensia dalam penelitian ini menggunakan analisis data time series Error Correction Model (ECM). Penggunaan analisis ECM bertujuan untuk mengetahui faktor penyebab MIT dalam jangka pendek dan mengambil tindakan yang tepat untuk menghindari atau keluar dari MIT dalam jangka panjang. Adapun tahapan pengujian pada ECM adalah uji stasioneritas, meregresikan variabel independen dengan variabel dependen untuk memperoleh persamaan jangka panjang, uji kointegrasi, persamaan jangka pendek (ECM) dan uji asumsi klasik.

Model ECM yang digunakan dalam penelitian ini adalah sebagai berikut:

$$
\begin{aligned}
& \triangle \text { PNBperkapita }_{t}=b_{0}+B_{1} \Delta \text { PMTB }_{t}+b_{2} \Delta \text { LnPertanian }_{t} \\
& +B_{3} \text { Ln } \Delta \text { Manufaktur } \\
& +b_{4} \Delta \text { LnJasa } \\
& +b_{5} \Delta \text { Pendidikan_TK } \\
& +b_{6} \dot{\varepsilon}_{t-1}+u_{t}
\end{aligned}
$$

Dengan:

$$
\begin{aligned}
\dot{\varepsilon}_{t-1}=E C T_{t-1}= & \text { Error Correction Term pada periode } \\
& k e(t-1)
\end{aligned}
$$

Sehingga model dapat dituliskan sebagai berikut: $\triangle$ PNBperkapita $_{t}=b_{0}+B_{1} \Delta P M T B_{t}+b_{2} \Delta$ LnPertanian $_{t}$

$$
\begin{aligned}
& +b_{3} \text { Ln } \text { M Manufaktur }_{t} \\
& +b_{4} \Delta \text { LnJasa }_{t}
\end{aligned}
$$




$$
+B_{5} \Delta \text { Pendidikan_TK }
$$$$
+B_{6} E C T_{t-1}+u_{t}
$$

Di mana:

\begin{tabular}{|c|c|c|}
\hline$\triangle P N B p e r k a p i t a t$ & : & $\begin{array}{l}\text { perubahan PNB per } \\
\text { kapita pada periode } t\end{array}$ \\
\hline$\Delta P M T B_{t}$ & : & $\begin{array}{l}\text { perubahan share PMTB } \\
\text { terhadap PDB pada } \\
\text { periode } t\end{array}$ \\
\hline$\Delta$ LnPertanian $_{t}$ & : & $\begin{array}{l}\text { perubahan In nilai } \\
\text { tambah pertanian pada } \\
\text { periode } t\end{array}$ \\
\hline$\Delta$ LnManufaktur ${ }_{t}$ & : & $\begin{array}{l}\text { perubahan In nilai } \\
\text { tambah manufaktur } \\
\text { pada periode } t\end{array}$ \\
\hline$\Delta$ LnJasa $_{t}$ & : & $\begin{array}{l}\text { perubahan In nilai } \\
\text { tambah jasa pada } \\
\text { periode } t\end{array}$ \\
\hline$\Delta$ Pendidikan_TK $K_{t}$ & : & $\begin{array}{l}\text { Jumlah tenaga kerja } \\
\text { dengan pendidikan } \\
\text { tinggi pada periode t }\end{array}$ \\
\hline$E C T_{t-1}$ & : & $\begin{array}{l}\text { Error Correction Term } \\
\text { pada periode ke (t-1) }\end{array}$ \\
\hline$u_{t}$ & . & $\begin{array}{l}\text { error term dari model } \\
\text { (2) pada periode } t\end{array}$ \\
\hline
\end{tabular}

Model ECM akan menjadi model yang valid jika variabel-variabel dalam model berkointegrasi dan didukung oleh koefisien variabel $E C T_{t-1}$ yang signifikan dan bernilai negatif. Koefisien $E C T_{t-1}$ disebut juga speed of adjustment yang menjelaskan seberapa cepat keseimbangan akan dikembalikan atau dengan kata lain fluktuasi keseimbangan jangka pendek akan dikoreksi menuju keseimbangan jangka panjang. Jika koefisien $E C T_{t-1}$ bernilai positif, arah variabel-variabel yang digunakan dalam model akan semakin menjauh dari keseimbangan jangka panjang sehingga model ECM tidak dapat digunakan. Sebaliknya, jika koefisien $E C T_{t-1}$ bernilai negatif, arah variabel-variabel yang digunakan dalam model akan semakin mendekat menuju keseimbangan jangka panjang.

Pengolahan data dalam penelitian ini akan dibantu dengan software Microsoft Excel 2010 dan Eviews 8. Microsoft Excel 2010 digunakan untuk membuat tabel dan grafik yang membantu dalam analisis deskriptif penelitian ini. Kemudian Eviews 8 digunakan dalam pembuatan model untuk memperoleh hasil tujuan penelitian dan pengujian asumsi.

\section{HASIL DAN PEMBAHASAN \\ Perkembangan variabel yang memengaruhi PNB Per Kapita \\ Menurut klasifikasi Bank Dunia, Indonesia} masuk dalam kelompok negara pendapatan menengah kebawah (lower-middle income country) dalam 13 tahun terakhir. Hal ini menunjukkan bahwa perekonomian Indonesia tidak mengalami pertumbuhan yang berarti (peningkatan pendapatan per kapita Indonesia cukup konstan) dalam waktu yang lama dan membuat potensi Indonesia masuk MIT sangat besar.

1) PNB Per Kapita

Perkembangan PNB per kapita Indonesia periode tahun 1976-2015 ditunjukkan pada Gambar 3 berikut:

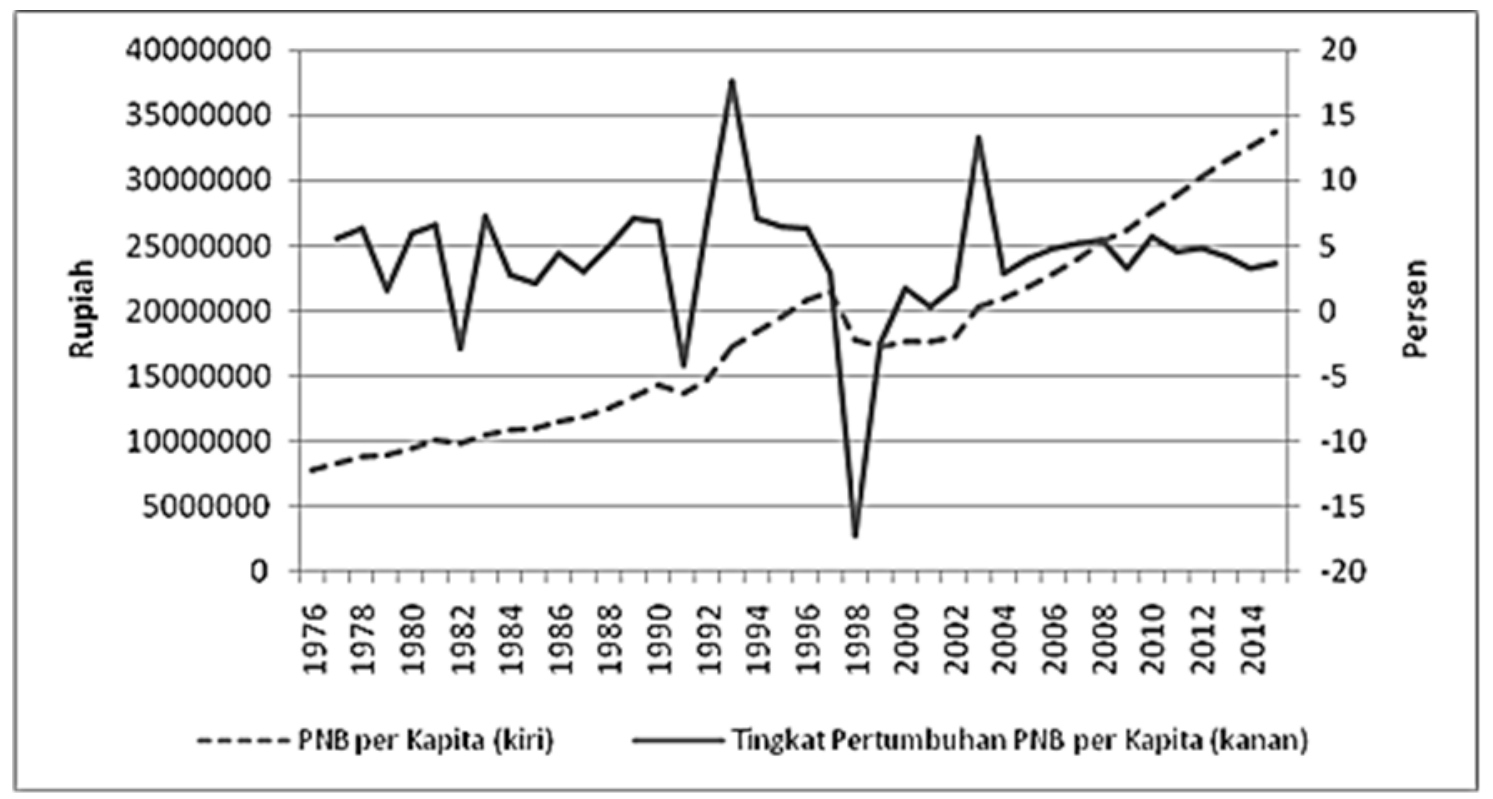

Sumber: World Bank (diolah).

Gambar 3. Perkembangan PNB per Kapita dan Tingkat Pertumbuhan PNB per Kapita di Indonesia atas Dasar Harga KonstanTahun 2010 Periode 1976-2015 


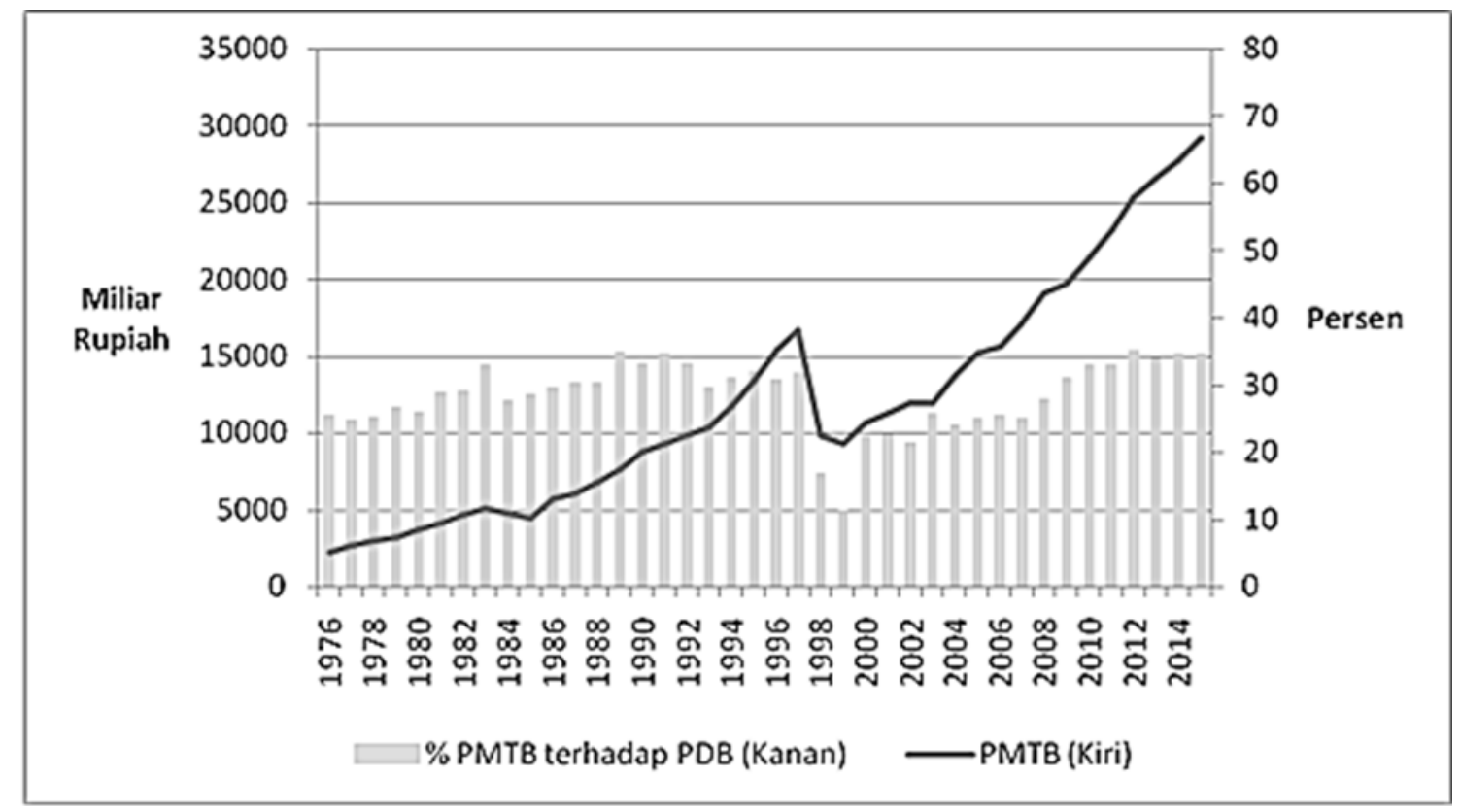

Sumber: Statistik Indonesia (BPS), diolah.

Gambar 4. Perkembangan PMTB Indonesia Periode 1976-2015

Secara umum PNB per kapita Indonesia menunjukkan peningkatan dari tahun 1976 hingga 2015. Pada tahun 1976 PNB per kapita Indonesia sebesar Rp7.844.751,734 dan pada tahun 2015 PNB per kapita Indonesia sebesar Rp33.734.009,517. Ini menunjukkan PNB per kapita Indonesia telah meningkat empat kali lipat sejak tahun 1976.

Pada kenyataannya, peningkatan angka pendapatan per kapita ini tidak dibarengi dengan peningkatan tingkat pertumbuhannya. Tingkat pertumbuhan ini berfluktuatif dari tahun 19762015. Tingkat pertumbuhan PNB per kapita tahun 1976 sampai 1997 dapat mencapai angka 5-6 persen dan bahkan menyentuh 17,57 persen pada tahun 1993. Namun pada tahun 1998 justru berbalik dengan tingkat pertumbuhan -17,22 persen sebagai pengaruh dari krisis ekonomi tahun 1998-1999.

Secara perlahan kondisi ekonomi Indonesia kembali pulih yang ditunjukkan dengan tingkat pertumbuhan yang meningkat secara drastis mencapai 13,29 persen pada tahun 2002. Perekonomian Indonesia yang mampu bertahan ini membawa Indonesia beralih dari kelompok negara pendapatan rendah ke negara berpendapatan menengah bawah (lower-middle income country), meskipun belum cukup cepat untuk mengantarkan Indonesia ke negara berpendapatan menengah atas (upper-middle income country).

Kondisi ini ternyata tidak bertahan cukup lama, peningkatan pertumbuhan ekonomi yang cukup tinggi justru perlahan-lahan semakin melambat bahkan konstan pada tahun-tahun berikutnya dengan rata-rata pertumbuhan hanya mencapai 3,89 persen. Pertumbuhan ekonomi yang sedang-sedang saja ini dikarenakan proses akumulasi, pembangunan sarana, serta alokasi sumber daya ekonomi masih jauh dari optimal.

Sesuai dengan penelitian Einchengreen, dkk (2016), kondisi PNB per kapita yang awalnya meningkat tajam dan pada tahun berikutnya menunjukkan pertumbuhan yang konstan bahkan menurun mengindikasikan bahwa Indonesia mengalami perlambatan pertumbuhan (growth slowdown) yang menjadi bukti bahwa Indonesia masuk kedalam MIT.

\section{2) PMTB}

Berdasarkan Gambar 4, terlihat bahwa share PMTB terhadap Pendapatan Domestik Bruto (PDB) berfluktuatif dari tahun 1976-2015. Pada tahun 1976 hingga tahun 1997, kontribusi investasi menunjukkan peningkatan yang cukup pesat yaitu dari 23,03 persen pada tahun 1976 hingga 53,56 persen pada tahun 1997. Penurunan yang drastis kemudian terjadi pada krisis 1998 dimana rasio PMTB Indonesia turun sebesar 17,05 persen dari tahun sebelumnya.

Meskipun tidak sebesar seperti pada periode sebelum krisis, komponen investasi secara perlahan menunjukkan peningkatan hingga tahun 2015 dengan rata-rata kontribusi 32,24 persen terhadap PDB tiap tahunnya. Peningkatan rasio investasi dalam hal ini PMTB, mengindikasikan bahwa iklim investasi di Indonesia selama satu dasawarsa terakhir cukup sehat. Peningkatan PMTB yang selaras dengan PNB per kapita menunjukkan bahwa semakin meningkat PMTB maka semakin banyak modal yang dapat digunakan sehingga akan meningkatkan output. 


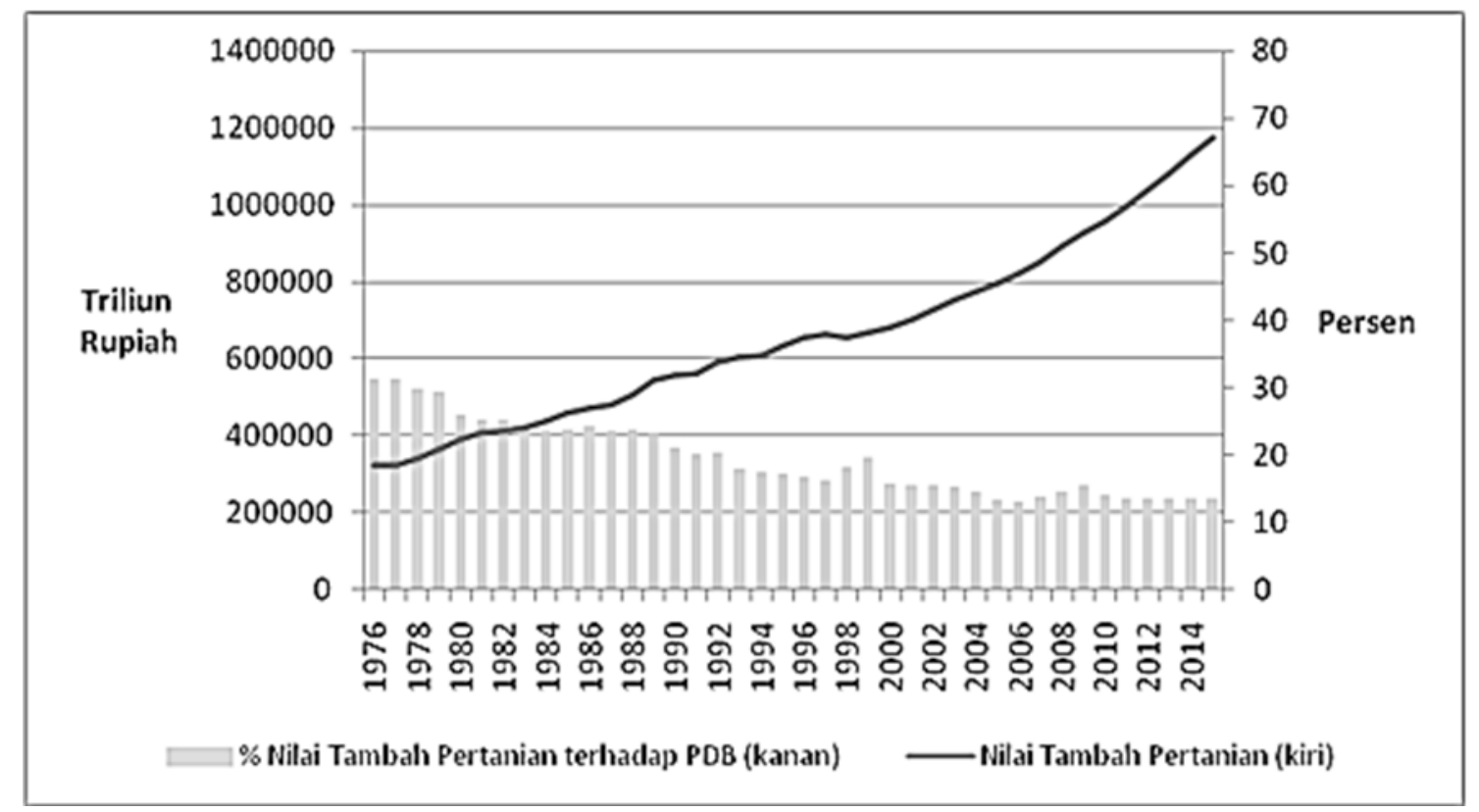

Sumber: Statistik Indonesia (BPS), diolah.

Gambar 5. Perkembangan Sektor Pertanian Indonesia Periode 1976-2015

\section{3) Pertanian}

Struktur perekonomian Indonesia merupakan bagian penting untuk menentukan arah kebijakan perekonomian Indonesia. Indonesia sebagai negara dengan jumlah penduduk 257 juta jiwa menjadi perhatian bagi pemerintah agar terpenuhi kesejahteraan dan kebutuhan pangannya. Selain itu, untuk mencanangkan transisi dari lower-middle income country menuju negara maju, Indonesia harus menguatkan sektor pertaniannya dalam menyokong industrialisasi pada tahap berikutnya. Untuk itu, sektor pertanian merupakan sektor penting dalam struktur perekonomian Indonesia.

Perkembangan pertanian Indonesia periode 1976-2015 (pada Gambar 5) menunjukkan tren yang positif. Nilai tambah pertanian yang awalnya sebesar Rp320.961 triliun menjadi Rp1.174.456 triliun pada tahun 2015. Hal ini menunjukkan pengelolaan sektor pertanian di Indonesia dalam periode tersebut sudah baik. Namun dari tahun ke tahun kontribusi sektor pertanian ini semakin menurun terhadap PDB, yaitu dari 31,29 persen pada tahun 1976 menjadi 13,52 persen di tahun 2015. Ini menunjukkan bahwa orientasi Indonesia di sektor primer mulai bertransisi menuju sektor lainnya seperti manufaktur dan jasa.

Menurut data BPS (2016), sebanyak 31 persen dari tenaga kerja Indonesia bekerja di sektor pertanian. Jadi peningkatan nilai tambah pertanian ini akan sangat berpengaruh langsung terhadap peningkatan PNB per kapita Indonesia.

\section{4) Manufaktur}

Jika dilihat dari kontribusinya terhadap PDB, sektor manufaktur menyumbang 10,93 persen dari
PDB pada 1976 dan terus meningkat hingga 28,71 persen pada tahun 2002. Bahkan pada masa krisis 1998 sektor ini masih mampu menyumbang 24,99 persen dari PDB. Selain itu, perkembangan industri manufaktur di sebuah negara dapat digunakan sebagai parameter perkembangan industri dan teknologi secara nasional. Karenanya perlu arahan dan kebijakan yang jelas dalam mengembangkan sektor manufaktur agar dapat membawa Indonesia bertransisi dari kelompok pendapatan menengah. Adapun perkembangan sektor manufaktur Indonesia periode 1976-2015 dapat dilihat pada Gambar 6 .

Berdasarkan Gambar 6, nilai tambah sektor manufaktur Indonesia memiliki tren yang meningkat dari tahun 1976 hingga 2015. Meskipun menunjukkan tren yang positif, pertumbuhan industri manufaktur ini semakin lama semakin kecil. Pada periode sebelum krisis 1998, sektor manufaktur ini mampu tumbuh rata-rata 12,55 persen tiap tahunnya. Namun, pada periode setelah krisis sektor ini hanya tumbuh dengan rata-rata 4,69 persen.

Kondisi pertumbuhan industri manufaktur yang melambat tersebut sangat dipengaruhi oleh kondisi global, misalnya nilai tukar yang tidak stabil akan membuat harga impor menjadi sangat tinggi dibandingkan sebelum krisis. Sehingga jika dipaksakan akan meningkatkan beban biaya produksi dan daya saing akan menurun. Selain itu, sektor industri manufaktur sangat berperan dalam penyerapan tenaga kerja, jika perlambatan pertumbuhan ini dibiarkan begitu saja dalam jangka panjang industri manufaktur ini justru akan menjadi faktor perlambatan perekonomian Indonesia pengurang dari perekonomian Indonesia. 


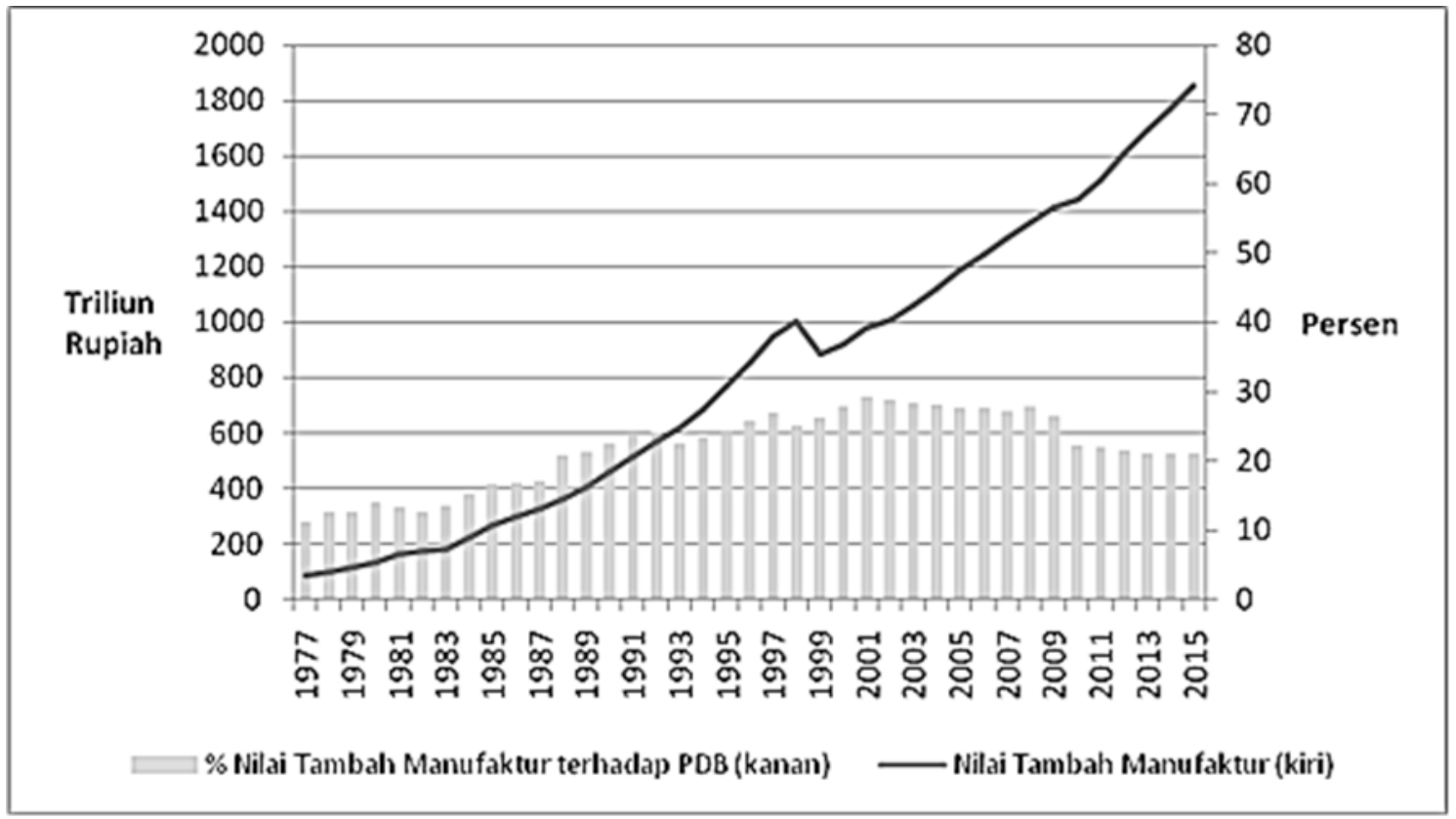

Sumber: Statistik Indonesia (BPS), diolah.

Gambar 6. Perkembangan Sektor Manufaktur Indonesia Periode 1976-2015

\section{5) Jasa}

Sektor jasa merupakan salah satu sektor yang paling menjanjikan untuk mendorong pertumbuhan ekonomi. Sebagian besar negara maju seperti Amerika Serikat dan Korea Selatan menjadikan sektor jasa sebagai orientasi perekonomiannya. Di Indonesia, sektor jasa menyumbang kontribusi paling tinggi terhadap PDB dibanding sektor pertanian dan manufaktur. Gambar 7 menunjukkan bahwa pada tahun 1976 sektor jasa memberikan kontribusi sebesar 38,28 persen terhadap PDB dan pada tahun 2015 berkontribusi sebesar 43,32 persen. Sektor ini cukup konstan dalam kontribusinya terhadap PDB dengan rata-rata kontribusi 40,31 persen tiap tahunnya.

Disamping kontribusinya yang konstan terhadap PDB, perkembangan sektor jasa juga meningkat selama periode 1976-2015. Pada tahun 1976 nilai tambah sektor jasa sebesar Rp314 triliun meningkat 10 kali lipat pada tahun 2015 menjadi Rp3,847 triliun. Peningkatan sektor jasa ini juga selaras dengan peningkatan PNB per kapita. Peningkatan output dari sektor jasa ini tidak hanya akan meningkatkan penghasilan tetapi juga menunjukkan kesejahteraan warga negara.

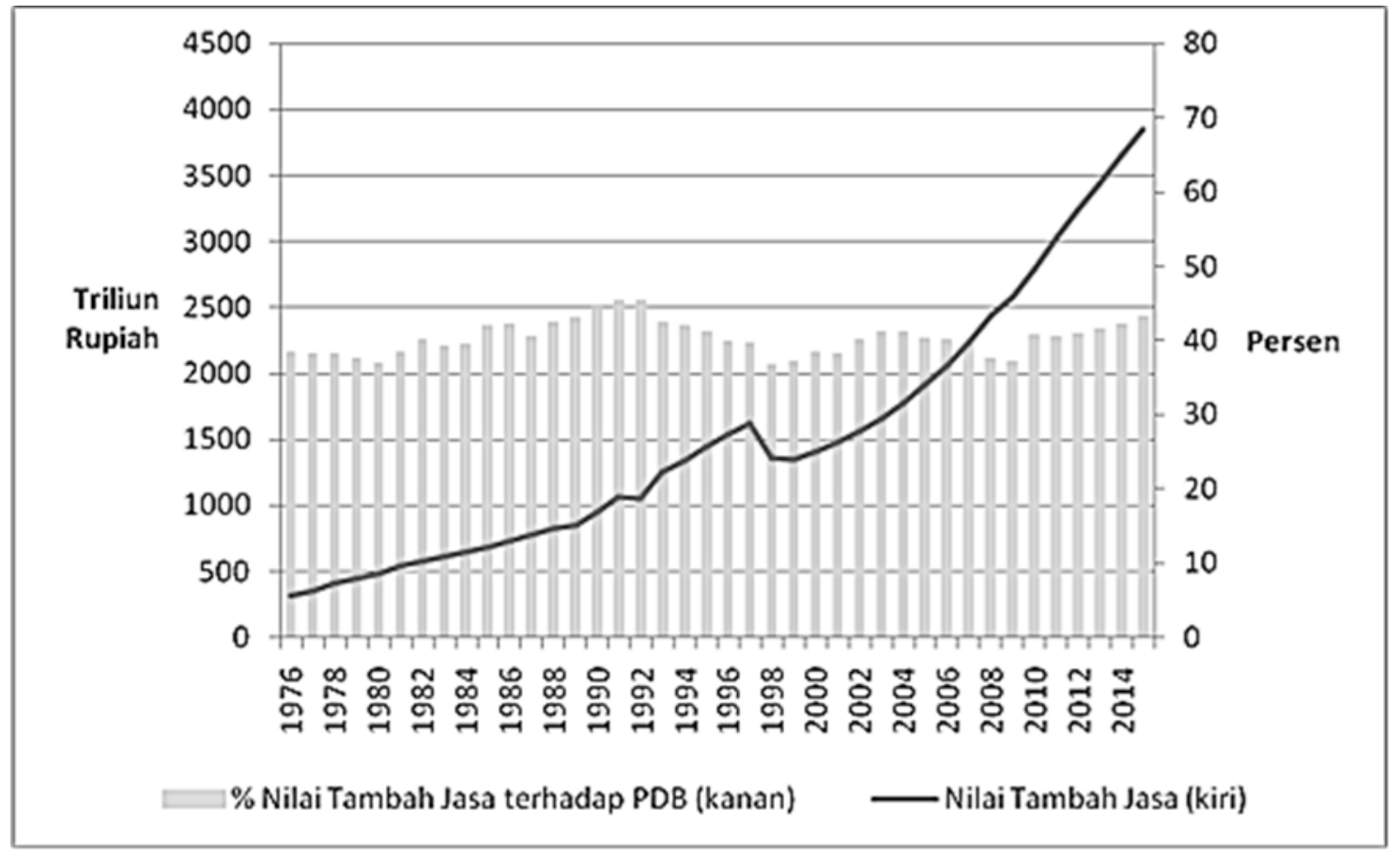

Sumber: Statistik Indonesia (BPS), diolah.

Gambar 7. Perkembangan Sektor Jasa Indonesia Periode 1976-2015 


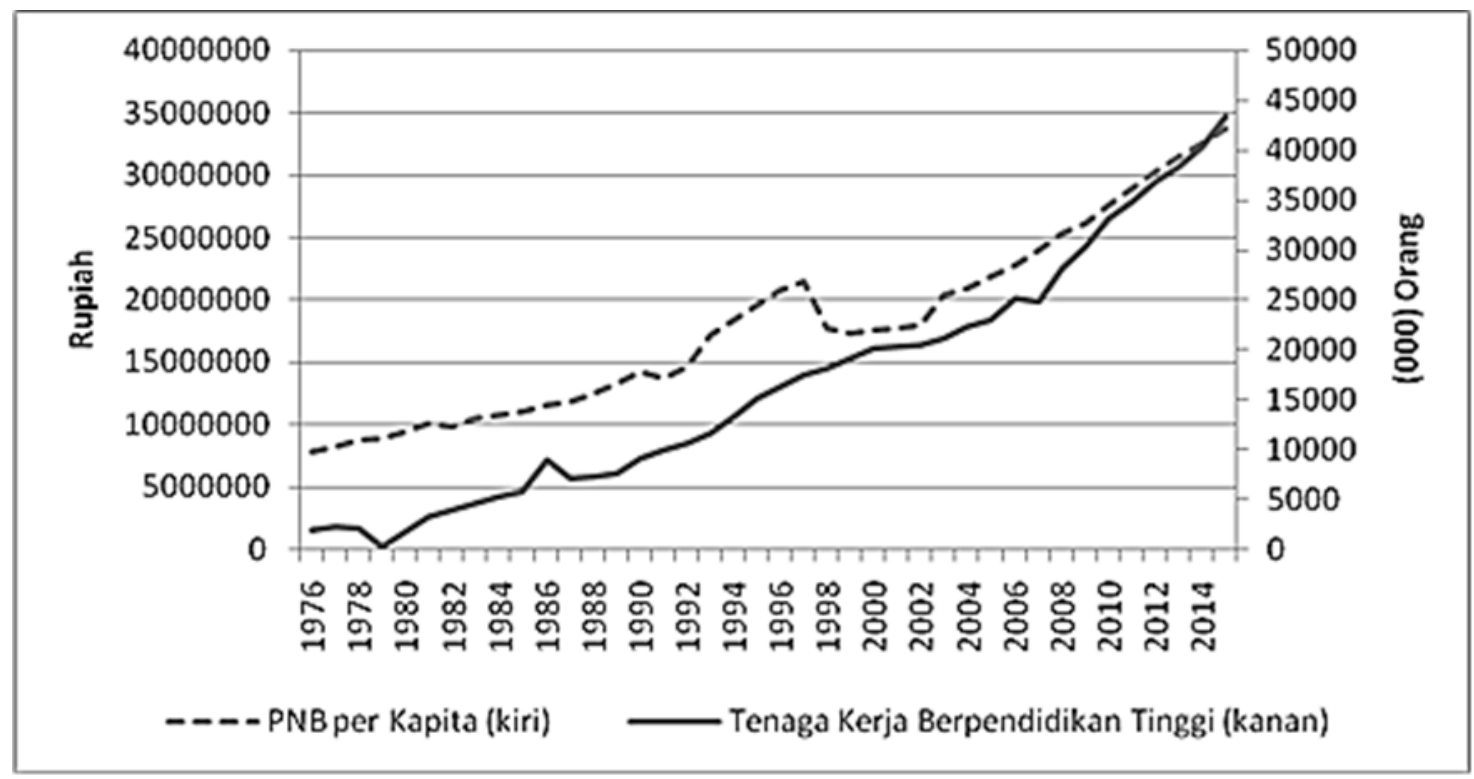

Sumber: Statistik Indonesia (BPS), diolah.

Gambar 8. Perkembangan Tenaga Kerja Dengan Pendidikan Tinggi Periode 1976- 2015

\section{6) Human Capital}

Struktur ekonomi sektor pertanian dan manufaktur dengan nilai tambah rendah umumnya bertumpu pada ketersediaan pekerja low-skill (berkeahlian rendah). Kondisi ini perlu dilakukan peralihan secara bertahap melalui peningkatan kualitas pekerja dari tingkat pendidikannya. Tenaga kerja dengan pendidikan yang tinggi akan mendorong pertumbuhan ekonomi karena akan lebih unggul dalam inovasi dan sadar teknologi dibandingkan dengan tenaga kerja yang tidak berpendidikan.

Jumlah tenaga kerja dengan pendidikan tinggi (lulusan SMA atau sederajat dan perguruan tinggi) semakin tahun semakin banyak. Ini menunjukkan bahwa tenaga kerja di Indonesia semakin berkualitas. Pada tahun 2015, jumlah tenaga kerja dengan pendidikan tinggi adalah sebesar 43,2 ribu orang dengan rincian 30,6 ribu orang tamatan SMA, 3 ribu orang tamatan Diploma dan 9,6 ribu orang lulusan universitas. Pembangunan human capital ini masih perlu peningkatan yang lebih agar komposisi tenaga kerja lulusan perguruan tinggi lebih besar kedepannya dibandingkan dengan lulusan SMA.

Perkembangan jumlah tenaga kerja dengan pendidikan tinggi ditunjukkan pada Gambar 8. Tren peningkatan jumlah tenaga kerja dengan pendidikan tinggi ini selaras dengan peningkatan PNB per kapita. Artinya, peningkatan kesejahteraan penduduk akan semakin tinggi seiring dengan bertambahnya jumlah tenaga kerja dengan pendidikan tinggi.

Pengaruh PMTB, pertanian, manufaktur, jasa dan pendidikan tenaga kerja terhadap PNB per kapita

Berdasarkan hasil regresiyang dihasilkan, persamaan jangka panjang yang terbentuk adalah sebagai berikut:
PNB perkapita $t_{t}=-42894284+88531,61 *$ PMTB $_{t}$

- 2876867 LnPertanian $_{t}$ $-4074872 *$ LnManufaktur $+0,406661 *$ Pendidikan_TK $(3)$

Keterangan: $\left.{ }^{*}\right)=$ signifikan pada $\alpha=5$ persen

Dari persamaan di atas dapat dilihat bahwa PMTB, jasa, dan pendidikan tenaga kerja berpengaruh signifikan terhadap PNB per kapita, sementara pertanian dan manufaktur justru berpengaruh negatif dalam jangka panjang. Secara simultan PMTB, pertanian, manufaktur, jasa, dan pendidikan tenaga kerja berpengaruh signifikan terhadap PNB per kapita. Hal ini dibuktikan dengan nilai $p$-value statistik uji $F$ sebesar 0,0000 lebih kecil dari $\alpha=5$ persen. Secara parsial variabel PMTB, jasa, dan pendidikan tenaga kerja berpengaruh positif dan signifikan pada $\alpha=5$ persen, sedangkan manufaktur berpengaruh signifikan negatif pada $\alpha=5$ persen.

Sementara untuk jangka pendek, model ECM dalam penelitian ini adalah sebagai berikut:

$$
\begin{aligned}
\mathrm{D}(\text { PNBperkapita })= & -538550+44593,90 \mathrm{D}\left(\text { PMTB }_{\mathrm{t}}\right) \\
& +12529258^{*} \mathrm{D}\left(\text { LnPertanian }_{\mathrm{t}}\right) \\
& -2691197 \mathrm{D}\left(\text { LnManufaktur }_{\mathrm{t}}\right) \\
& +11372486^{*} \mathrm{D}\left(\text { LnJasa }_{\mathrm{t}}\right) \\
& +0,245634^{*} \\
& \mathrm{D}(\text { Pendidikan_TK }
\end{aligned}
$$

Keterangan: $\left.{ }^{*}\right)=$ signifikan pada $\alpha=5$ persen

Dari persamaan ECM di atas, secara simultan PMTB, pertanian, manufaktur, jasa, dan pendidikan tenaga kerja berpengaruh signifikan terhadap PNB per kapita. Hal ini dibuktikan dari nilai $p$-value uji $\mathrm{F}$ sebesar 0,0000 lebih kecil dari $\alpha=5$ persen. Sementara secara parsial yang berpengaruh signifikan adalah variabel pertanian, jasa, pendidikan tenaga kerja dan Error Correction Term (ECT) pada $\alpha=5$ persen. 
Dapat disimpulkan dari persamaan ECM yang diperoleh bahwa seluruh variabel independen yang digunakan dalam penelitian mampu menjelaskan 63,79 persen variasi dalam PNB per kapita. Sedangkan sisanya 36,21 persen, dijelaskan oleh variabel lain di luar model.

ECT dalam model menunjukkan speed of adjustment (kecepatan untuk kembali menuju keseimbangan jangka panjang) sebesar 0,42921. Nilai koefisien ECT sebesar 0,42921 ini menunjukkan bahwa fluktuasi keseimbangan jangka pendek akan dikoreksi menuju keseimbangan jangka panjang, dimana sekitar 42,92 persen proses adjustment-nya terjadi pada tahun pertama dan 57,08 persen proses adjustment terjadi pada tahun-tahun berikutnya.

Dalam jangka pendek pertumbuhan sektor pertanian berpengaruh positif dan signifikan pada $\alpha=5$ persen terhadap PNB per kapita yaitu sebesar 12.529.258. Nilai ini menunjukkan bahwa pertumbuhan output pertanian sebesar 1 persen akan meningkatkan PNB per kapita sebesar Rp125.292,58 dengan asumsi ceteris paribus. Hasil ini sesuai hipotesis awal dimana peningkatan sektor pertanian akan meningkatkan PNB per kapita. Hasil yang diperoleh sama dengan penelitian yang dilakukan oleh Joel Chongela (2015) yang memperoleh hasil bahwa sektor pertanian memiliki pengaruh positif terhadap perekonomian di Tanzania.

Pertumbuhan sektor jasa juga berpengaruh positif dan signifikan terhadap PNB per kapita pada $\alpha=5$ persen yaitu sebesar 11.372.486. Nilai ini menunjukkan bahwa peningkatan output sektor jasa sebesar 1 persen akan meningkatkan PNB per kapita sebesar Rp113.724,86 dengan asumsi ceteris paribus. Hasil ini sesuai dengan hipotesis awal yang mengatakan bahwa peningkatan sektor jasa akan memengaruhi peningkatan PNB per kapita.

Pertumbuhan pendidikan tenaga kerja berpengaruh positif dan signifikan pada $\alpha=5$ persen terhadap PNB per kapita yaitu sebesar 0,245634 . Meskipun sangat kecil, bertambahnya 1 orang tenaga kerja dengan pendidikan tinggi akan memengaruhi peningkatan PNB per kapita sebesar Rp0,245634 dengan asumsi ceteris paribus. Hasil ini sejalan dengan teori sebelumnya bahwa human capital berpengaruh positif terhadap pertumbuhan ekonomi.

PMTB berpengaruh positif terhadap PNB per kapita dalam jangka pendek, tetapi secara statistik tidak berpengaruh signifikan dalam $\alpha=5$ persen. Sementara sektor manufaktur berpengaruh negatif terhadap PNB per kapita, namun sama halnya dengan PMTB tidak signifikan dalam $\alpha=5$ persen.

Dalam jangka pendek, sektor pertanian dan sektor jasa berpengaruh signifikan terhadap PNB per kapita. Ini menunjukkan bahwa kedua sektor tersebut sangat berperan aktif dalam peningkatan kesejahteraan penduduk Indonesia. Di sisi lain, sektor manufaktur belum begitu berpengaruh terhadap PNB per kapita. Hal ini menunjukkan bahwa selama ini struktur perekonomian Indonesia tidak berperan secara bersama-sama, karena hanya sektor pertanian dan jasa yang memberikan pengaruh terhadap PNB per kapita.

Suatu negara dikatakan memiliki struktur perekonomian yang baik apabila perekonomiannya ditunjang oleh tiga sektor yaitu pertanian, manufaktur, dan jasa (Lashmi dan Kumar, 2012) dan untuk bertransisi menuju negara maju, seharusnya suatu negara melewati tahapan transformasi dari ketiga struktur perekonomian tersebut. Sementara dari hasil yang diperoleh, Indonesia tidak melewati tahapan transisi di sektor manufaktur dengan baik, namun mendapatkan penguatan di sektor pertanian dan langsung ke jasa.

Kondisi ini tidak cukup baik bagi perekonomian Indonesia karena sektor manufaktur akan lebih menyerap jumlah tenaga kerja dibandingkan dengan sektor jasa. Sehingga, jumlah penduduk Indonesia yang banyak nantinya tidak akan termanfaatkan dengan baik dan bonus demografi yang seharusnya menguntungkan akan menjadi masalah besar dalam pembangunan Indonesia. Hal inilah yang menjadi penyebab pertumbuhan ekonomi menjadi stagnan dan membuat Indonesia terjebak dalam pendapatan menengah.

Sementara manufaktur yang awalnya tidak signifikan justru menjadi signifikan dalam jangka panjang di $\alpha=5$ persen. Tapi ternyata pertumbuhan manufaktur ini dalam jangka panjang berpengaruh negatif terhadap PNB per kapita. Peranan sektor manufaktur ini sangat dikhawatirkan akan menjadi pengurang bagi perekonomian Indonesia dalam jangka panjang.

Hal ini bisa disebabkan oleh sektor pertanian Indonesia yang tidak cukup kuat. Karena pada dasarnya sektor pertanian harus menjadi pondasi untuk menghasilkan bahan baku dan modal di sektor manufaktur. Terbukti dari hasil persamaan jangka panjang yang menunjukkan bahwa sektor pertanian menjadi tidak signifikan secara statistik dalam $\alpha$ = 5 persen. Hasil ini juga sesuai dengan penelitian yang dilakukan oleh Tambunan, et al. (2011), dimana dalam jangka panjang sektor manufaktur (pendekatan nilai ekspor manufaktur) berpengaruh negatif terhadap PDB.

Sektor manufaktur yang menjadi pengurang dari PNB per kapita diakibatkan oleh manufaktur di Indonesia yang masih memiliki produksi berbasis bahan mentah. Hal ini jelas tidak dapat diunggulkan 
baik dari segi kualitas, teknologi, dan infrastrukturnya. Selain itu, bahan baku yang digunakan masih banyak dari bahan impor ketimbang mengandalkan supply pertanian dalam negeri sebagai bahan baku. Jika produksi ini dapat beralih ke barang jadi/setengah jadi, maka nilai tambah yang dihasilkan pasti akan lebih besar dan dapat menguatkan perekonomian Indonesia.

Kondisi ini mengindikasikan bahwa perkembangan sektor manufaktur melambat dan perannya digantikan oleh sektor jasa yang pertumbuhannya lebih tinggi dari PDB. Perlambatan sektor manufaktur yang menurun ini bertentangan dengan pola umum negara besar lain seperti Cina dan Korea Selatan. Padahal negara besar seperti Indonesia dengan jumlah penduduk yang besar dan kekayaan alam yang melimpah seharusnya memiliki kemampuan membangun industri yang besar dibandingkan negara kecil karena memiliki pasar domestik yang luas dan berkontribusi signifikan terhadap perekonomian.

Perkembangan jangka panjang sektor manufaktur Indonesia yang berbeda ini menunjukkan bahwa transformasi struktur ekonomi di Indonesia tidak berjalan dengan baik. Hal inilah yang mengindikasikan bahwa Indonesia telah masuk kedalam MIT. Sementara negara besar lainnya, menunjukkan pola berbeda seperti Cina yang telah bertransisi ke upper-middle income country dan Korea Selatan ke high income dalam jangka waktu yang sama. Indonesia seharusnya bisa mencapainya.

Investasi dalam hal ini PMTB yang awalnya tidak signifikan dalam jangka panjang signifikan dan positif pada $\alpha=5$ persen. Ini sesuai dengan teori HarrodDomar yang menjelaskan bahwa semakin banyak yang diinvestasikan semakin cepat pergerakan perekonomian. Investasi ini perlu menjadi perhatian dan ditingkatkan sebagai salah satu jalan keluar dari MIT. Dengan bertambahnya investasi maka modal untuk pembangunan dan perbaikan infrastruktur semakin cepat, aktivitas perekonomian menjadi baik dan dapat meningkatkan pendapatan penduduk.

Peningkatan sektor jasa dapat digunakan sebagai salah satu upaya untuk menghindari MIT, dikarenakan sektor ini memiliki kontribusi yang signifikan terhadap PNB per kapita baik dalam jangka pendek maupun jangka panjang. Secara statistik sektor jasa berpengaruh signifikan dalam jangka panjang pada $\alpha=5$ persen.

Peningkatan sektor jasa ini telah didiskusikan dalam Rencana Pembangunan Jangka Menengah Nasional (RPJMN) 2015-2019, yang berfokus pada peningkatan daya saing dalam rangka mengurangi defisit neraca pembayaran. Kebijakan ini juga terkait dengan pembatasan impor jasa seperti penyedia jasa transportasi dan jasa keuangan. Namun, hal ini belum mencakup pengembangan sektor jasa yang meningkatkan kualitas dan daya saing dalam perekonomian secara umum.

Peningkatan human capital juga merupakan salah satu upaya menghindari MIT. Salah satu cara peningkatan human capital adalah melalui pendidikan. Hal ini dibuktikan dengan hasil dimana pendidikan tenaga kerja dalam jangka pendek maupun jangka panjang secara statistik berpengaruh positif dan signifikan di $\alpha=5$ persen terhadap PNB per kapita.

Peningkatan kualitas tenaga kerja ini juga sejalan dengan temuan Hanushek dan Ludger (2016) bahwa tenaga kerja dengan pendidikan tinggi dan terampil memiliki efek yang lebih tinggi dalam pertumbuhan ekonomi karena memiliki kemampuan yang lebih dalam inovasi dan lebih cepat dalam menguasai teknologi. Selain itu, tenaga kerja dengan pendidikan yang tinggi biasanya memiliki kompensasi yang lebih tinggi dibandingkan dengan tenaga kerja dengan pendidikan rendah.

Dengan demikian, peningkatan pendidikan di Indonesia perlu ditingkatkan untuk menghasilkan tenaga-tenaga kerja yang terampil sehingga pertumbuhan yang cepat dan berkelanjutan dapat terjadi dan akan membuat Indonesia terhindar dari MIT. Kebijakan dalam peningkatan human capital ini akan sangat terasa dampaknya pada periode 2020-2030 mendatang, dimana bonus demografi akan menyediakan tenaga kerja yang berlimpah bagi perekonomian nasional.

Meskipun dalam jangka panjang investasi dan sektor jasa berpengaruh signifikan terhadap PNB per kapita bukan berarti harus mengabaikan sektor pertanian dan manufaktur. Seperti kebanyakan negara maju, meskipun berorientasi di sektor jasa mereka tidak meninggalkan pertanian dan manufakturnya. Negara-negara maju pada awalnya menitikberatkan pembangunan ekonomi negaranya pada sektor pertanian kemudian berangkat ke sektor industri manufaktur.

Dalam peralihannya dari sektor pertanian ke sektor industri manufaktur harus dipastikan bahwa sektor pertanian mendapat prioritas dalam pembangunan tersebut. Belajar dari kondisi industri manufaktur Indonesia saat ini, bahan baku yang seharusnya berasal dari sektor pertanian justru tergantikan dari bahan baku impor. Sebagai contoh kebanyakan negara maju tidak meninggalkan sektor pertanian bahkan pertanian mendapat proteksi yang besar dari negara dalam bentuk subsidi dan bantuan lainnya. Dengan demikian perlu dilakukannya perbaikan dalam struktur pertanian dan manufaktur di Indonesia serta peningkatan baik dalam investasi 
dalam hal ini PMTB, sektor jasa, dan human capital seperti pendidikan tenaga kerja sehingga peningkatan pendapatan penduduk tercapai dan pada akhirnya Indonesia dapat terhindar dari jebakan pendapatan menengah (MIT).

\section{KESIMPULAN}

Penelitian ini dapat memberikan kesimpulan bahwa Indonesia telah mengalami jebakan pendapatan menengah (MIT). Hal ini dibuktikan bahwa dalam jangka pendek PNB per kapita secara signifikan hanya dipengaruhi oleh sektor pertanian dan sektor jasa, sedangkan sektor manufaktur tidak terbukti memengaruhi PNB per kapita. Dalam jangka panjang PMTB, sektor jasa, dan tenaga kerja berpendidikan tinggi berpengaruh signifikan positif, sementara sektor manufaktur justru menjadi pengurang dari PNB per kapita. Kondisi perekonomian yang tidak didukung secara bersamasama oleh ketiga sektor membuat perekonomian Indonesia berjalan stagnan dan terjebak dalam MIT.

Peningkatan struktur ekonomi di sektor jasa, PMTB, dan jumlah tenaga kerja dengan pendidikan tinggi (human capital) merupakan upaya-upaya yang perlu dilakukan agar keluar dari MIT. Hasil analisis membuktikan bahwa ketiga variabel tersebut memiliki dampak signifikan positif terhadap peningkatan PNB per kapita. Sementara sektor pertanian tidak signifikan dalam jangka panjang dan manufaktur tidak signifikan dalam jangka pendek.

\section{SARAN}

Berdasarkan hasil dan kesimpulan penelitian ini diperoleh saran-saran sebagai berikut:

- Meskipun telah bertransisi ke sektor manufaktur dan sektor jasa, sektor pertanian tidak berarti harus ditinggalkan. Pemerintah perlu melakukan perbaikan di sektor pertanian baik dalam bentuk subsidi bagi petani, peningkatan infrastruktur, dan penggunaan teknologi di bidang pertanian.

- Sektor manufaktur Indonesia yang masih berbasis produksi raw material sebaiknya ditingkatkan ke produksi bahan jadi/setengah jadi agar menghasilkan nilai tambah yang lebih tinggi. Selain itu, perlunya penguatan penggunaan hasil pertanian dalam negeri sebagai bahan baku untuk industri manufaktur dibanding penggunaan bahan baku impor.

- Peningkatan investasi dapat dilakukan dalam sektor-sektor strategis seperti telekomunikasi, transportasi, bandara, pelabuhan, perbankan dan infrastruktur dasar lainnya.

- Pemerintah sebaiknya mempermudah akses finansial dan mempermudah perizinan di bidang perdagangan terkait ekspor-impor untuk meningkatkan sektor jasa.

Peningkatan kualitas human capital dapat dilakukan melalui: perekrutan tenaga kerja dengan klasifikasi pendidikan tinggi, pemberian pelatihan, kursus singkat, dan beasiswa bagi karyawan tamatan SMA kebawah baik dari perusahaan swasta maupun instansi pemerintah. Penelitian selanjutnya diharapkan dapat menggali lebih rinci ke dalam sembilan sektor utama dan menganalisis MIT di level provinsi.

\section{DAFTAR PUSTAKA}

\section{Buku}

Baltagi, Badi.H. (2008). Econometrics (4 $\left.4^{\text {th }} e d\right)$. New York: Springer.

Bappenas. (2015). Rencana pembangunan jangka menengah (RPJMN 2015-2019). Jakarta: Bappenas.

Box George \&Gwilym M. Jenkins. (1970). Time series analysis forecasting and control. California: Holden-Day.

BPS RI. (2013). Statistik industri manufaktur Indonesia 2013. Jakarta: BPS RI.

BPS RI. (2015). Statistik Indonesia 2015. Jakarta: BPS RI.

BPS RI. (2016). Statistik Indonesia 2016. Jakarta: BPS RI.

Dajan, Anto. (1986). Pengantar metode statistik jilid II. Jakarta: PT Pustaka LP3ES Indonesia.

Dumairy. (1999). Perekonomian Indonesia. Jakarta: Erlangga.

Enders W. (2004). Applied econometrics time series $\left(2^{\text {nd }} e d\right)$. New York : John Wiley \& Son Inc.

Gujarati, D.N. (2004). Basic econometrics (4thed). New York: McGraws-Hill Companies.

Juanda, B, \& Junaidi. (2012). Ekonometrika deret waktu: Teori dan aplikasi. Bogor: IPB Press.

Kementrian Keuangan Republik Indonesia. (2016). Profil utang pemerintah pusat. Jakarta: Kemenkeu.

Kothler, Philip., Armstrong, \& Garry. (2008). Prinsipprinsip Pemasaran Jilid 1. Jakarta: Erlangga. 
Mankiw, N.G. (2007). Macroeconomics. New York: Worth Publisher.

Montgomery, D.C., Lynwood, A.J., \& John, S.G. (1990). Forecasting and time series analysis $\left(2^{\text {nd }}\right.$ Edition). Singapura: McGraw Hill Inc.

OECD. (2016). Education policy outlook: Korea. Paris: OECD.

Sukirno, Sadono. (2006). Makroekonomi. Jakarta: PT Raja Grafindo Persada.

Tambunan, Tulus. (2015). Perekonomian Indonesia. Bogor: Ghalia Indonesia.

Todaro, M.P. \& Smith, S.C. (2003). Pembangunan ekonomi di dunia ketiga $\left(8^{\text {th }} e d\right)$. Jakarta: Erlangga.

World Bank. (1989). Per capita income. Washington: World Bank.

\section{Jurnal}

Aviliani, Hermanto, S., \& Heni, H. (2014). Addressing the middle-income trap: Experience of Indonesia. Asian Social Science, 10(7), 163-172.

Bulman, D., Maya, E., \& Ha Nguyen. (2016). Transitioning from low-income growth to highincome growth: Is there a middle-income trap? Tokyo: Asian Development Bank Institute.

Gill, Indermit \& Homi, K. (2007). An East Asian Renaissance: Ideas for economic growth. Washington DC: World Bank.

Im, F.G. \& Rosenbalt, D. (2013). Middle-income trap - a conceptual and empirical survey. Policy Research Working Paper, 6594.

Kharas, H. \& Kohli, H. (2011). What is the middle income trap, why do countries fall into it, and how can it be avoided?. Global Journal of Emerging Market Economies, 3(3), 281-289.

Lubis, R \& Putu, M.A.S. (2015). The middle-income trap: Is there a way out for asian countries? Journal of Indonesian Economy and Business, 30(3), 283-287.

Malale, A \& Maung, A.S. (2014). Analisis middleincome trap di Indonesia. Jurnal BPPK, 7(2), 91110.

Oberman, R., Richard, D., Arief, B., Fraser, T., \& Morten, R. (2012). The archipelago economy: Unleashing Indonesia's potential. McKinsey Global Institution.
Ohno, Kenichi. (2009). Avoiding the middle-income trap: Renovating industrial policy formulation in Vietnam. Asean Economic Buletin, 26(1), 25-43.

Paus, Eva. (2014). Latin America and the middleincome trap. Amerika Serikat: ECLAC.

Pruchnik, K \& Jakub, Z. (2016). Middle-income trap: Review of the conceptual framework. Tokyo: Asian Development Bank.

Tambunan, et al. (2011). Analisis pengaruh ekspor industri manufaktur pada kinerja makroekonomi Indonesia. Jurnal Organisasi dan Manajemen, 7(2), 75-85.

\section{Sumber digital}

Agenor, P.R., Otaviano, C., Michael, J. (2012). Avoiding middle-income growth traps. Economic Premise 98, 1-7. Diperoleh tanggal 1 November 2016 dari http://siteresources.worldbank.org/ EXTPREMNET/Resources/EP98.pdf

Aiyar, S., Romain, D., Damien, P., Yiqun, W., \& Longmei, Z. (2013). Growth slowdowns and middle-income trap. IMF Working Paper, 13(71). Diperoleh tanggal 16 Februari 2017 dari https:// www.imf.org/external/pubs/ft/wp/2013/ wp1371.pdf

Chongela, Joel. (2015). Contribution of agriculture to the Tanzanian economy. American Journal of Research Communication, 3(7), 57-70. Diperoleh tanggal 20 Juli 2017 dari http://www.usajournals.com/wp-content/uploads/2015/06/ Chongela_Vol37.pdf

Eichengreen, B., Donghyun, P., \& Kwanho, S. (2013). Growth slowdowns redux: New evidence on the middle-income trap. NBER Working Paper, 18673. Diperoleh tanggal 24 Oktober 2016 dari http://www.nber.org/paper/w18673.ack

Fischer, Stanley. (1983). Inflation and growth. National Bureau of Economic Research, 1235. Diperoleh tanggal 8 Maret 2017 dari http:// citeseerx.ist.psu.edu/viewdoc/download?doi=1 0.1.1.694.1430\&rep=rep1\&type=pdf

Garrett, G. (2004). Globalization's missing middle foreign affair, 83(6), 84-96. Diperoleh tanggal 7 Maret 2017 dari https://www.foreignaffairs. com/articles/2004-11-01/globalizationsmissing-middle

Glawe, L dan Helmut, W. (2016). The middle-income trap - defenitions, theories and countries concerned: a literature survey. MPRA Paper, 71196. Diperoleh tanggal 7 Maret 2017 dari https://mpra.ub.uni-muenchen.de/71196/ 
Hanushek, E \& Ludger, W. (2016). The role of education quality for economic growth. World Bank Policy Research Working Paper, 4122. Diperoleh tanggal 20 Juli 2017 dari https:// papers.ssrn.com/sol3/papers.cfm?abstract_ id $=960379$

Lashmi, P \& Kumar, S. (2012). Economic growth and impact of service's sector in India. Internasional Journal Bussines Management Economic Research, 3(5), 627-632. Diperoleh tanggal 20 Juli 2017 dari http://www.ijbmer.com/docs/ volumes/vol3issue5/ijbmer2012030504.pdf

Robertson, P \& Longfeng, Ye. (2013). On the existence of a middle income trap. Economic Discussion Paper, 13(12). Diperoleh tanggal 24 Oktober 2016 dari https://www.hhs.se/contentassets/ c9558a10642a49d9815eeb09f189b9dc/on-theexistence-of-a-middle-income-trap.pdf

Tasar, I., Esma G. \& Yunus A., (2016). Is Turkey in A Middle Income Trap?. Journal of Applied Research in Finance and Economic, 1(1), 36-41. Diperoleh tanggal 27 Maret 2017 dari http:// www.jarfe.org/index.php/jarfe/article/view/5/5

World Bank. (2016). World development indicators. Diperoleh tanggal 26 Maret 2017, dari http:// databank.worldbank.org/data/reports. aspx ? source $=2 \&$ series $=$ NY.GNP.PCAP. KN\& country=IDN

\section{LAMPIRAN}

Lampiran 1. Hasil uji akar unit variabel pada level

Null Hypothesis: Unit root (individual unit root process)

Series: PNBPERKAPITA, PMTB, LNPERTANIAN, LNMANUFAKTUR, LNJASA, PENDIDIKAN_TK

Date: 09/08/17 Time: 07:39

Sample: 19762015

Exogenous variables: Individual effects, individual linear trends

Automatic selection of maximum lags

Automatic lag length selection based on SIC: 0 to 1

Total number of observations: 233

Cross-sections included: 6

\begin{tabular}{lcc}
\hline \hline Method & Statistic & Prob. $^{\star \star}$ \\
\hline ADF - Fisher Chi-square & 5.06139 & 0.9559 \\
ADF - Choi Z-stat & 1.59528 & 0.9447 \\
\hline \hline
\end{tabular}

** Probabilities for Fisher tests are computed using an asymptotic Chi -square distribution. All other tests assume asymptotic normality.

Intermediate ADF test results UNTITLED

\begin{tabular}{ccccc}
\hline \hline & & & & \\
Series & Prob. & Lag & Max Lag & Obs \\
\hline PNBPERKAPITA & 0.7831 & 1 & 9 & 38 \\
PMTB & 0.5708 & 0 & 9 & 39 \\
LNPERTANIAN & 0.7043 & 0 & 9 & 39 \\
LNMANUFAKTUR & 0.6953 & 0 & 9 & 39 \\
LNJASA & 0.3684 & 0 & 9 & 39 \\
PENDIDIKAN_TK & 0.9873 & 0 & 9 & 39 \\
\hline \hline
\end{tabular}

Lampiran 2. Hasil uji akar unit variabel pada difference 1

Null Hypothesis: Unit root (individual unit root process)

Series: PNBPERKAPITA, PMTB, LNPERTANIAN, LNMANUFAKTUR LNJASA, PENDIDIKAN TK

Date: 09/08/17 Time: 07:41

Sample: 19762015

Exogenous variables: Individual effects, individual linear trends

Automatic selection of maximum lags

Automatic lag length selection based on SIC: 0

Total (balanced) observations: 228

Cross-sections included: 6

\begin{tabular}{lcc}
\hline \hline Method & Statistic & Prob. $^{* \star}$ \\
\hline ADF - Fisher Chi-square & 85.4373 & 0.0000 \\
ADF - Choi Z-stat & -7.61685 & 0.0000 \\
\hline
\end{tabular}

${ }^{* \star}$ Probabilities for Fisher tests are computed using an asymptotic Chi -square distribution. All other tests assume asymptotic normality.

Intermediate ADF test results D(UNTITLED)

\begin{tabular}{ccccc}
\hline \hline & & & & \\
Series & Prob. & Lag & Max Lag & Obs \\
\hline D(PNBPERKAPI... & 0.0030 & 0 & 9 & 38 \\
D(PMTB) & 0.0028 & 0 & 9 & 38 \\
D(LNPERTANIAN) & 0.0033 & 0 & 9 & 38 \\
D(LNMANUFAK... & 0.0017 & 0 & 9 & 38 \\
D(LNJASA) & 0.0008 & 0 & 9 & 38 \\
D(PENDIDIKAN... & 0.0000 & 0 & 9 & 38 \\
\hline \hline
\end{tabular}


Lampiran 3. Persamaan Jangka Panjang

Dependent Variable: PNBPERKAPITA

Method: Least Squares

Date: 08/23/17 Time: 00:43

Sample: 19762015

Included observations: 40

\begin{tabular}{lrrrr}
\hline \hline \multicolumn{1}{c}{ Variable } & Coefficient & Std. Error & t-Statistic & Prob. \\
\hline \hline C & -42894284 & 44126876 & -0.972067 & 0.3379 \\
PMTB & 88531.62 & 27649.00 & 3.201982 & 0.0030 \\
LNPERTANIAN & -2876867. & 5338684. & -0.538872 & 0.5935 \\
LNMANUFAKTUR & -4074872. & 1035634 & -3.934663 & 0.0004 \\
$\quad$ LNJASA & 10250283 & 3150334. & 3.253713 & 0.0026 \\
PENDIDIKAN_TK & 0.406661 & 0.081415 & 4.994928 & 0.0000 \\
\hline \hline R-squared & 0.990892 & Mean dependent var & 17982967 \\
Adjusted R-squared & 0.989553 & S.D. dependent var & 7394741. \\
S.E. of regression & 755829.5 & Akaike info criterion & 30.04650 \\
Sum squared resid & $1.94 E+13$ & Schwarz criterion & 30.29983 \\
Log likelihood & -594.9300 & Hannan-Quinn criter. & 30.13810 \\
F-statistic & 739.8084 & Durbin-Watson stat & 1.120174 \\
Prob(F-statistic) & 0.000000 & & & \\
\hline \hline
\end{tabular}

Lampiran 4. Uji Kointegrasi

Null Hypothesis: ECT has a unit root

Exogenous: Constant Linear Trend

Lag Length: 0 (Automatic - based on SIC, maxlag=9)

\begin{tabular}{lccc}
\hline \hline & & t-Statistic & Prob. $^{*}$ \\
\hline \hline Augmented Dickey-Fuller test statistic & -3.965527 & 0.0184 \\
\hline Test critical values: & $1 \%$ level & -4.211868 & \\
& $5 \%$ level & -3.529758 & \\
& $10 \%$ level & -3.196411 & \\
\hline \hline
\end{tabular}

*MacKinnon (1996) one-sided p-values.

Lampiran 5. Persamaan Jangka Pendek (Error Correction Mechanism)

\begin{tabular}{|c|c|c|c|c|}
\hline \multicolumn{5}{|c|}{$\begin{array}{l}\text { Dependent Variable: D(PNBPERKAPITA) } \\
\text { Method: Least Squares } \\
\text { Date: 08/23/17 Time: } 00: 44 \\
\text { Sample (adjusted): } 19772015 \\
\text { Included observations: } 39 \text { after adjustments }\end{array}$} \\
\hline Variable & Coefficient & Std. Error & t-Statistic & Prob. \\
\hline C & -538550.0 & 277351.7 & -1.941759 & 0.0610 \\
\hline D(PMTB) & 44593.90 & 31882.99 & 1.398674 & 0.1715 \\
\hline D(LNPERTANIAN) & 12529258 & 5990248. & 2.091609 & 0.0445 \\
\hline D(LNMANUFAKTUR) & -2691197 & 2139615 . & -1.257795 & 0.2176 \\
\hline D(LNJASA) & 11372486 & 2459625 . & 4.623666 & 0.0001 \\
\hline D(PENDIDIKAN_TK) & 0.245634 & 0.089702 & 2.738344 & 0.0100 \\
\hline $\mathrm{ECT}(-1)$ & -0.429216 & 0.142962 & -3.002308 & 0.0052 \\
\hline R-squared & 0.695049 & \multicolumn{2}{|c|}{ Mean dependent var } & 663827.1 \\
\hline Adjusted R-squared & 0.637871 & \multicolumn{2}{|c|}{ S.D. dependent var } & 960224.6 \\
\hline S.E. of regression & 577836.0 & \multicolumn{2}{|c|}{ Akaike info criterion } & 29.53312 \\
\hline Sum squared resid & $1.07 \mathrm{E}+13$ & \multicolumn{2}{|c|}{ Schwarz criterion } & 29.83170 \\
\hline Log likelihood & -568.8958 & \multirow{2}{*}{\multicolumn{2}{|c|}{$\begin{array}{l}\text { Hannan-Quinn criter. } \\
\text { Durbin-Watson stat }\end{array}$}} & 29.64025 \\
\hline F-statistic & 12.15582 & & & 1.508364 \\
\hline Prob(F-statistic) & 0.000000 & & & \\
\hline
\end{tabular}

Lampiran 6. Uji Asumsi Normalitas Persamaan ECM

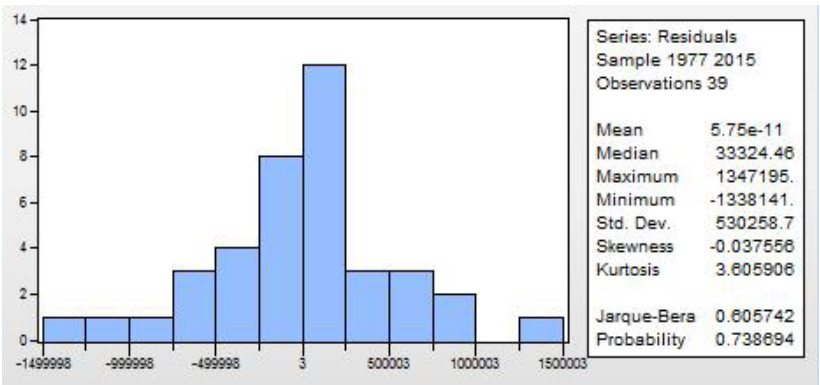

Lampiran 7. Uji Asumsi Nonautokorelasi Persamaan ECM

Breusch-Godfrey Serial Correlation LM Test:

\begin{tabular}{llll}
\hline \hline F-statistic & 2.205516 & Prob. $F(4,28)$ & 0.0941 \\
Obs*R-squared & 9.343867 & Prob. Chi-Square(4) & 0.0531 \\
\hline \hline
\end{tabular}

Lampiran 8. Uji Asumsi Homoskedastisitas Persamaan ECM

Heteroskedasticity Test: Breusch-Pagan-Godfrey

\begin{tabular}{llll}
\hline \hline F-statistic & 1.834851 & Prob. F(6,32) & 0.1235 \\
Obs*R-squared & 9.982889 & Prob. Chi-Square(6) & 0.1254 \\
Scaled explained SS & 8.757008 & Prob. Chi-Square(6) & 0.1877 \\
\hline \hline
\end{tabular}

Lampiran 9. Uji Asumsi Multikolinearitas Persamaan ECM

Variance Inflation Factors

Date: 08/23/17 Time: 00:47

Sample: 19762015

Included observations: 39

\begin{tabular}{cccc}
\hline \hline Variable & $\begin{array}{c}\text { Coefficient } \\
\text { Variance }\end{array}$ & $\begin{array}{c}\text { Uncentered } \\
\text { VIF }\end{array}$ & $\begin{array}{c}\text { Centered } \\
\text { VIF }\end{array}$ \\
\hline \hline C & $7.69 \mathrm{E}+10$ & 8.984978 & NA \\
D(PMTB) & $1.02 \mathrm{E}+09$ & 1.883013 & 1.874071 \\
D(LNPERTANIAN) & $3.59 \mathrm{E}+13$ & 5.976887 & 1.339677 \\
D(LNMANUFAKTUR) & $4.58 \mathrm{E}+12$ & 5.314144 & 1.898307 \\
D(LNJASA) & $6.05 \mathrm{E}+12$ & 4.850771 & 1.940193 \\
D(PENDIDIKAN_TK) & 0.008046 & 2.229940 & 1.170324 \\
ECT(-1) & 0.020438 & 1.186462 & 1.186399 \\
\hline \hline
\end{tabular}

